Jurnal Agroteknologi, Vol. 8 No. 1, Agustus $2017: 11-16$

\title{
PENGARUH APLIKASI INSEKTISIDA BERBAHAN AKTIF ASETAMIPRID TERHADAP ULAT PENGGULUNG PUCUK (Cydia leucostoma) PADA TANAMAN TEH
}

\author{
(The Effect of Insecticide with Active Ingredients Acetamiprid to Tea Shoot Roller \\ (Cydia Leucostoma) on Tea Plant) \\ FANI FAUZIAH DAN HILMAN MAULANA \\ Pusat Penelitian Teh dan Kina Gambung, \\ Desa Mekarsari, Kec. Pasirjambu, Kab. Bandung 40972. \\ e-mail : fani_fauziah@ymail.com, Tlp. (022) 5928185, Faks : (022) 5928185.
}

\begin{abstract}
Tea Shoot roller (Cydia leucostoma Meyrick) is one potential pests that attack tea shoot, mainly on the new tea shoot after prunning, it caused plant growth becomes stunted. One of control that can be done is by application of insecticides. To determine the effectiveness of insecticide Acetamiprid, the trial has been conducted at Block A7, Gambung field trial, Kabupaten Bandung, during \pm 3 months, from October up to December 2016. The trial was designed in Randomized Complete Block Design (RCBD) with five treatments and four replications. The treatment tested covered insecticide Asetamiprid 30\% at 1; 0.75; 0.50; $0.25 \mathrm{l} / \mathrm{ha}$ and control. The insecticide was sprayed six times using knapsack sprayer one day after plucking, with one week interval. Tea shoot roller attack intensity was observed weekly at the time of plucking. Shoot production, phytotoxicity, as well as rainfall were also observed as a supporting data. The results showed that after three times of spraying, insecticide Asetamiprid 30\% at all formulation doses tested could effectively suppress the attack intensity of tea shoot roller. The last observation result, after six times spraying, revealed that the average efficacy level relatively high, i.e. $73,24 \%$. Therefore, for controlling tea shoot roller on tea it could be recommended the use of insecticide Asetamiprid $30 \%$.
\end{abstract}

Keywords : acetamiprid, tea shoot roller, tea

\section{PENDAHULUAN}

Hama penggulung pucuk teh (Laspeyresia leucostoma Meyrick) merupakan salah satu hama potensial yang menyerang tanaman teh. Ulat penggulung pucuk menyerang tanaman teh pada bagian pucuk. Salah satu kerugian yang ditimbulkan akibat serangan hama penggulung pucuk adalah tergulungnya pucuk daun teh sehingga mengakibatkan pertumbuhan tanaman menjadi terhambat. Serangan $L$. leucostoma terjadi sepanjang tahun, terutama pada tanaman teh yang baru tumbuh kembali setelah pemangkasan (Pusat Penelitian Teh dan Kina, 2006).

Ngengat betina bertelur dengan meletakkan satu atau dua telur per daun teh. Ulat yang telah menetas akan langsung menuju pucuk dan menggulung daun pucuk dengan menggunakan benang-benang halus sehingga pucuk menjadi tergulung. Ulat secara bertahap membuat sarang dan makan dari bagian dalam sarang. Dua hari sebelum menjadi kepompong, ulat berhenti makan dan mulai melipat daun dipinggirnya. Dalam lipatan daun, ulat membuat kepompong berwarna putih (Peraturan Menteri Pertanian, 2014).

Pengendalian ulat penggulung pucuk dapat dilakukan dengan berbagai cara, antara lain dengan melakukan pemetikan pucuk daun teh yang terserang; cara hayati dengan menggunakan musuh alami seperti Apanteles; dan cara kimiawi dengan insektisida. Penggunaan insektisida merupakan cara yang dinilai paling efektif untuk mengendalikan ulat penggulung pucuk. Beberapa bahan aktif insektisida yang dapat digunakan untuk mengendalikan ulat penggulung pucuk antara lain kuinalfos, karbaril, tetraklorvinfos, dan metidation (PPTK, 2006). Penggunaan insektisida harus dilaksanakan secara bijaksana dengan tepat jenis, dosis, anjuran, sasaran, cara, waktu aplikasi dan menggunakan pestisida yang telah terdaftar dan memperoleh izin (Permentan, 2014). Berdasarkan daftar Pestisida Pertanian dan Kehutanan 2016, keempat bahan aktif tersebut tidak terdaftar untuk mengendalikan ulat penggulung pucuk pada tanaman teh. Oleh karena itu, perlu diketahui efektivitas bahan aktif insektisida lain yang telah terdaftar dan dapat dijadikan sebagai 
alternatif untuk mengendalikan ulat penggulung pucuk.

\section{BAHAN DAN METODE}

Insektisida Asetamiprid 30\% (setara dengan Asetamiprid 27,708 gram) yang diuji merupakan insektisida kontak dan sistemik berbentuk pekatan yang dapat diemulsikan. Percobaan dilakukan selama \pm 4 bulan, dari Bulan September hingga Desember, di Blok A7, Kebun Percobaan Gambung, Kabupaten
Bandung, Jawa Barat dengan ketinggian tempat $1.350 \mathrm{~m}$ di atas permukaan laut. Lahan percobaan yang digunakan adalah areal tanaman teh produktif klon GMB 7, dengan umur tanaman \pm 2 tahun setelah pangkas. Petak percobaan yang digunakan berukuran $(10 \times 10)$ $\mathrm{m}^{2}$, dengan batas antar plot $2 \mathrm{~m}$.

Percobaan dirancang dalam Rancangan Acak Kelompok dengan 5 perlakuan dan diulang sebanyak 5 kali. Perlakuan yang diuji disajikan pada Tabel 1. berikut :

Tabel 1. Perlakuan yang diuji

\begin{tabular}{cccc}
\hline No. & Kode & Perlakuan & Dosis (I/ha) \\
\hline 1 & A & Asetamiprid 30\% & 1 \\
2 & B & Asetamiprid 30\% & 0,75 \\
3 & C & Asetamiprid 30\% & 0,5 \\
4 & D & Asetamiprid 30\% & 0,25 \\
5 & E & Kontrol (tanpa perlakuan) & - \\
\hline
\end{tabular}

Aplikasi Insektisida dilakukan dengan cara penyemprotan menggunakan alat semprot punggung, dengan volume semprot 400 liter per ha. Penyemprotan dilakukan satu hari setelah pemetikan, sebanyak 6 kali aplikasi dengan interval aplikasi 1 minggu. Pengamatan dilakukan 1 minggu sekali pada saat pemetikan, sebanyak 9 kali, yang terdiri dari 3 kali pengamatan pendahuluan, dan 6 kali pengamatan setelah aplikasi perlakuan. Parameter pengamatan utama adalah intensitas serangan ulat penggulung pucuk. Sebagai data pendukung, diamati pula produksi pucuk teh, fitotoksisitas, dan curah hujan.

Intensitas serangan ulat penggulung pucuk ditentukan dengan cara menghitung jumlah pucuk $p+3$ yang sehat dan yang terinfeksi dari 100 pucuk sampel yang diambil secara acak dari hasil pucuk per petak. Intensitas serangan ulat penggulung pucuk dihitung dengan rumus :

$$
\mathrm{I}=\frac{\mathrm{a}}{\mathrm{a}+\mathrm{b}} \times 100
$$

$\mathrm{I}=$ intensitas hama $(\%)$

$\mathrm{a}=$ Jumlah pucuk $\mathrm{p}+3$ yang terserang

$b=$ Jumlah pucuk $p+3$ yang sehat

Dari hasil pengamatan terakhir dihitung tingkat efektivitas insektisida, dengan rumus :

$$
E I=\frac{l_{k}-l_{p}}{l_{k}} \times 100
$$

$\mathrm{EI}=$ Efektivitas Insektisida (\%)

$I_{k}=$ Intensitas serangan hama pada kontrol (\%)

$I_{p}=$ Intensitas serangan hama perlakuan (\%)

Pengamatan keracunan tanaman atau fitotoksisitas akibat penyemprotan insektisida ditentukan dengan nilai skala yang didasarkan atas persentase daun yang menunjukkan gejala keracunan pada tiap petak percobaan. Penilaian fitotoksisitas ditentukan sebagai berikut :

1. Tidak fitotoksisitas (tidak ada daun yang menunjukkan gejala keracunan)

2. Fitotoksisitas rendah (1-10\% daun dari unit contoh menunjukkan gejala keracunan)

3. Fitotoksisitas sedang (11-25\% daun dari unit contoh menunjukkan gejala keracunan)

4. Fitotoksisitas tinggi (26-100\% daun dari unit contoh menunjukkan gejala keracunan)

Data intensitas serangan ulat penggulung pucuk dan produksi pucuk teh dianalisis secara statistic dengan menggunakan Analisis Sidik Ragam (Analyses of Variance), dilanjutkan dengan uji beda rata-rata dengan menggunakan Uji Duncan.

\section{HASIL DAN PEMBAHASAN}

Efektivitas insektisida Asetamiprid $30 \%$
terhadap ulat penggulung pucuk
Hasil pengamatan pendahuluan sebanyak 3 kali menunjukkan bahwa pada awal percobaan sebelum aplikasi perlakuan (penyemprotan), kondisi serangan ulat 
Jurnal Agroteknologi, Vol. 8 No. 1, Agustus $2017: 11-16$

penggulung pucuk dengan rata-rata $\pm 31,29 \%$ pengamatan pendahuluan ke-3, yang

merupakan kondisi awal sebelum aplikasi perlakuan (Tabel 2, Gambar 3).

Tabel 2. Intensitas Serangan Penggulung Pucuk Pada Awal Percobaan

\begin{tabular}{llll}
\hline Perlakuan & PP1 & PP2 & PP3 \\
\hline A. Asetamiprid 30\% 1 I/ha & $36,12 \mathrm{~b}$ & $36,93 \mathrm{c}$ & $34,80 \mathrm{~b}$ \\
B. Asetamiprid 30\% 0,75 I/ha & $38,39 \mathrm{~b}$ & $36,58 \mathrm{c}$ & $32,31 \mathrm{ab}$ \\
C. Asetamiprid 30\% 0,50 I/ha & $32,60 \mathrm{ab}$ & $33,69 \mathrm{bc}$ & $32,48 \mathrm{ab}$ \\
D. Asetamiprid 30\% 0,25 I/ha & $28,61 \mathrm{a}$ & $30,11 \mathrm{ab}$ & $28,94 \mathrm{a}$ \\
E. Kontrol & $25,27 \mathrm{a}$ & $28,21 \mathrm{a}$ & $27,93 \mathrm{a}$ \\
\hline
\end{tabular}

${ }^{*}$ Angka rata-rata yang diikuti oleh huruf yang sama menunjukkan tidak berbeda nyata menurut Uji Jarak Berganda Duncan pada taraf 0,05\%

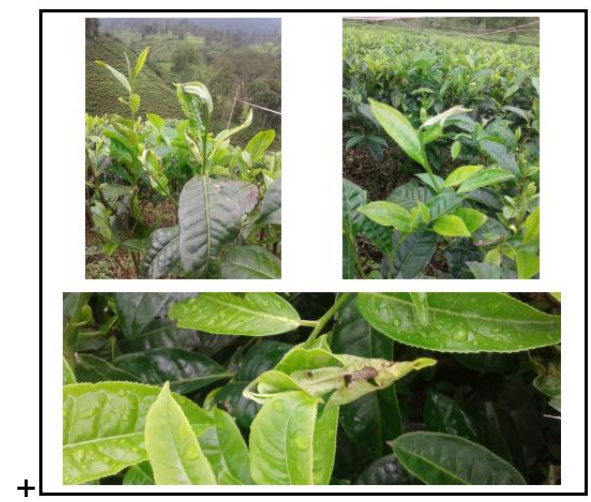

Gambar 3. Gejala serangan hama penggulung pucuk pada awal percobaan

\begin{abstract}
Hasil pengamatan setelah aplikasi perlakuan (penyemprotan) (Tabel 3) menunjukkan bahwa perlakuan insektisida Asetamiprid $30 \%$ mulai menunjukkan efektivitasnya setelah 3 kali penyemprotan. Pada tiga kali pengamatan, yaitu pada pengamatan setelah aplikasi ke-3, intensitas serangan pada ketiga dosis Asetamiprid 30\% (1 I/ha, $0,75 \mathrm{l} / \mathrm{ha}$, dan $0,5 \mathrm{l} / \mathrm{ha}$ ) tidak berbeda nyata satu sama lain namun lebih rendah jika dibandingkan dengan dosis 0,25 I/ha dan
\end{abstract}

kontrol. Pada pengamatan ke-5 setelah aplikasi intensitas serangan ulat penggulung pucuk tidak berbeda nyata antar dosis Asetamiprid 30\%.

Pada pengamatan ke-4 setelah aplikasi, intensitas serangan ulat penggulung pucuk pada dosis $1 \mathrm{l} /$ ha dan $0,50 \mathrm{l} /$ ha tidak berbeda nyata. Sementara itu, pada pengamatan terakhir (pengamatan ke-6 setelah aplikasi) menunjukkan bahwa intensitas serangan ulat penggulung pucuk pada dosis $0,75 \mathrm{I} /$ ha dan 0,5 I/ha tidak berbeda nyata satu sama lain.

Tabel 3. Intensitas Serangan Penggulung Pucuk Pada Berbagai Perlakuan Insektisida Asetamiprid 30\% Setelah Aplikasi Perlakuan

\begin{tabular}{llccccc}
\hline \multicolumn{1}{c}{ Perlakuan } & $\mathbf{1}$ & $\mathbf{2}$ & $\mathbf{3}$ & $\mathbf{4}$ & $\mathbf{5}$ & $\mathbf{6}$ \\
\hline A. Asetamiprid 30\% 1 I/ha & 25,38 & 17,67 & $16,98 \mathrm{a}$ & $10,19 \mathrm{a}$ & $9,54 \mathrm{a}$ & $4,76 \mathrm{a}$ \\
B. Asetamiprid 30\% 0,75 I/ha & 25,88 & 18,73 & $16,36 \mathrm{a}$ & $13,76 \mathrm{ab}$ & $13,00 \mathrm{a}$ & 8,31 \\
C. Asetamiprid 30\% 0,50 I/ha & 28,33 & 21,71 & $17,56 \mathrm{a}$ & $12,24 \mathrm{a}$ & $11,77 \mathrm{a}$ & $8,02 \mathrm{ab}$ \\
D. Asetamiprid 30\% 0,25 I/ha & 27,17 & 24,30 & $21,35 \mathrm{~b}$ & $17,26 \mathrm{~b}$ & $14,35 \mathrm{a}$ & $10,87 \mathrm{~b}$ \\
E. Kontrol & 29,1 & 23,68 & $29,92 \mathrm{c}$ & $27,75 \mathrm{c}$ & $28,53 \mathrm{~b}$ & $29,86 \mathrm{c}$ \\
\hline Signifikansi & $\mathrm{NS}$ & $\mathrm{NS}$ & & & \\
\hline
\end{tabular}

*Angka rata-rata yang diikuti oleh huruf yang sama menunjukkan tidak berbeda nyata menurut Uji Jarak Berganda Duncan pada taraf 0,05\%; NS = Not Significant

Intensitas serangan ulat penggulung pucuk terus menurun hingga pengamatan terakhir (pengamatan ke-6 setelah aplikasi) pada seluruh perlakuan Asetamiprid 30\% (Gambar 4). Berdasarkan hasil uji statistik menunjukkan bahwa aplikasi insektisida Asetamiprid 30\% pada seluruh dosis dapat menurunkan intensitas serangan ulat penggulung pucuk. Namun, dosis Asetamiprid 30\% $1 \mathrm{l} /$ ha menunjukkan penurunan intensitas serangan ulat penggulung pucuk terendah hingga $4,76 \%$ pada pengamatan ke-6 setelah aplikasi. 
Insektisida Asetamiprid termasuk kedalam golongan Neonikotinoid. Mode of Action dari golongan neonikotinoid adalah menyerang system syaraf secara spesifik pada Nicotinic acethylcholine receptor (nAChR). Insektisida tersebut akan meniru tindakan agonis asetilkolin di nAChRs yang merupakan neurotransmitter utama dalam sistem saraf pusat serangga. Hal tersebutakan menyebabkan hipereksitasi pada syaraf serangga (Insecticide Resistance Action Committee, 2016).

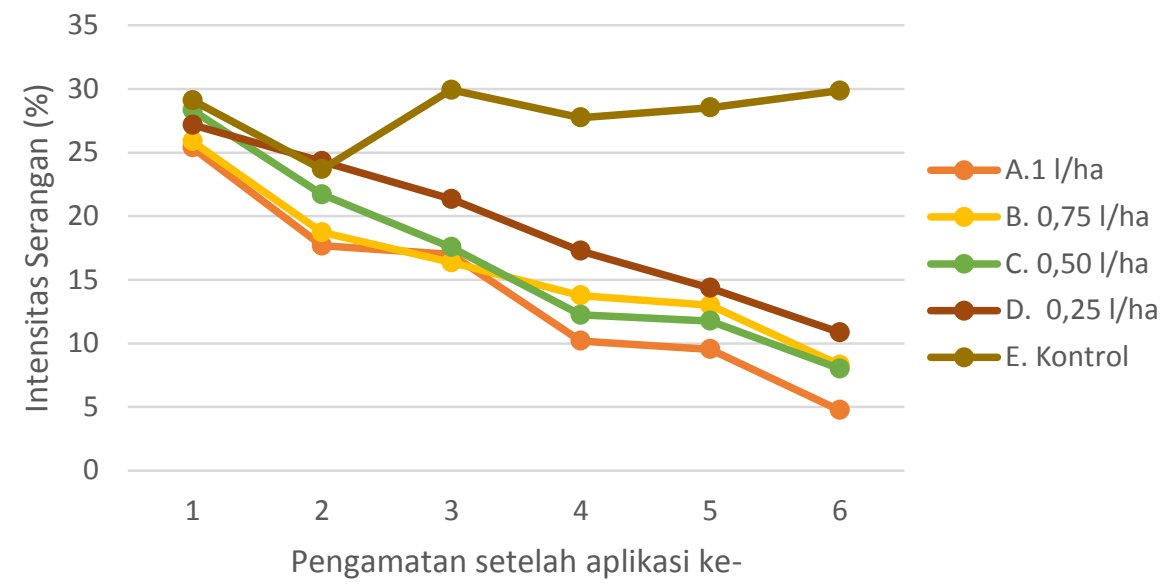

Gambar 4. Intensitas Serangan Hama Penggulung Pucuk Pada Berbagai Perlakuan Asetamiprid 30\% Setelah Aplikasi Perlakuan

Dari hasil pengamatan terakhir setelah 6 kali penyemprotan, dapat diketahui bahwa rata-rata tingkat efektivitas (TE) insektisida Asetamiprid $30 \%$ sangat tinggi, mencapai $\pm 73,24 \%$. Dengan demikian, tingkat efektivitas insektisida Asetamiprid $30 \%$ lebih dari $70 \%$, sesuai dengan tingkat efektivitas yang diharapkan dari suatu insektisida (Tabel 4).

Tabel 4. Efektivitas Berbagai Dosis Formulasi Insektisida Asetamiprid 30\% Terhadap Hama Penggulung Pucuk pada Pengamatan Terakhir

\begin{tabular}{lll}
\hline Perlakuan & $\begin{array}{l}\text { Intensitas serangan hama } \\
(\%) *\end{array}$ & $\begin{array}{l}\text { Tingkat Efektivitas (TE) } \\
(\%))^{* *}\end{array}$ \\
\hline A. Asetamiprid 30\% 1 I/ha & 4,76 a & 84,06 \\
B. Asetamiprid 30\% 0,75 I/ha & 8,31 ab & 72,17 \\
C. Asetamiprid 30\% 0,50 I/ha & 8,02 ab & 73,14 \\
D. Asetamiprid 30\% 0,25 I/ha & $10,87 \mathrm{~b}$ & 63,60 \\
E. Kontrol & $29,86 \mathrm{c}$ & - \\
\hline Rata-rata TE (\%) & & 73,24 \\
\hline
\end{tabular}

* Setelah aplikasi perlakuan (penyemprotan) ke-6

Angka rata-rata yang diikuti oleh huruf yang sama menunjukkan tidak berbeda nyata menurut Uji Jarak Berganda Duncan pada taraf 0,05\%

${ }^{* *} T E=((I k-I p) / l k) \times 100$

$l k=$ Intensitas serangan hama pada kontrol (\%)

Ip = Intensitas serangan hama pada perlakuan (\%)

Salah satu yang mempengaruhi tingkat efektivitas insektisida adalah Mode of Action. Mode of Action merupakan kemampuan pestisida dalam mematikan hama atau penyakit sasaran menurut cara masuknya bahan beracun ke jasad hama atau penyakit sasaran dan menurut sifat dari bahan kimia tersebut. Berdasarkan cara masuknya, Asetamiprid merupakan insektisida dengan golongan racun perut dan racun kontak. Racun perut merupakan bahan beracun yang dapat merusak sistem pencernaan jika tertelan oleh serangga, sedangkan racun kontak merupakan bahan beracun pestisida yang dapat membunuh atau mengganggu perkembangbiakan serangga, jika bahan beracun tersebut mengenai tubuh serangga (Hudayya dan Jayanti, 2012; IRAC, 2016). Oleh karena itu, dengan kedua mekanisme tersebut tingkat efektivitas yang 
dicapai oleh insektisida Asetamiprid 30\% relatif tinggi dengan rata-rata lebih dari $70 \%$.

$\mathrm{Hal}$ ini juga sejalan dengan hasil penelitian Chen dkk., (2007) bahwa tingkat efektivitas Asetamiprid terhadap telur Contarinia nasturtii pada bibit kembang kol sangat tinggi hingga mencapai $100 \%$.

\section{Pengaruh insektisida Asetamiprid 30\% terhadap produksi pucuk basah}

Hasil analisis statistik terhadap produksi pucuk teh kumulatif dari 9 kali pemetikan menunjukkan bahwa perlakuan insektisida Asetamiprid $30 \%$ pada dosis 0,25 l/ha, menghasilkan produksi pucuk yang berbeda nyata dengan kontrol (Tabel 5). Produksi pucuk pada aplikasi Asetamiprid $30 \%$ dosis $0,50 \mathrm{l} / \mathrm{ha}$ sebanding dengan kontrol. Berdasarkan hasil tersebut, tampak bahwa pengaruh perlakuan insektisida Asetamiprid 30\% terhadap intensitas serangan ulat penggulung pucuk sejalan dengan pengaruhnya terhadap produksi pucuk. Efektivitas insektisida Asetamiprid 30\% dalam menekan intensitas serangan hama, dapat menghasilkan produksi pucuk yang lebih tinggi dari kontrol. Namun, produksi pucuk pada aplikasi Asetamiprid 30\% dosis $1 \mathrm{l} /$ ha dan 0,75 I/ha lebih rendah jika dibandingkan dengan kontrol. Hal ini dapat disebabkan oleh tingginya intensitas serangan ulat penggulung pucuk pada awal aplikasi insektisida, yang menyebabkan kehilangan hasil akibat serangan ulat penggulung pucuk cukup tinggi.

Tabel 5. Rata-Rata Produksi Pucuk Basah pada Berbagai Perlakuan Insektisida Asetamiprid 30\%

\begin{tabular}{|c|c|}
\hline Perlakuan & Rata-rata Produksi pucuk basah $\left(\mathrm{kg} / 100 \mathrm{~m}^{2}\right)^{*}$ \\
\hline A. Asetamiprid $30 \% 1 \mathrm{l} / \mathrm{ha}$ & $22,33^{a}$ \\
\hline B. Asetamiprid $30 \% 0,75 \mathrm{l} / \mathrm{ha}$ & $23,66^{a}$ \\
\hline C. Asetamiprid $30 \% 0,50 \mathrm{l} / \mathrm{ha}$ & $27,76^{\mathrm{ab}}$ \\
\hline D. Asetamiprid $30 \% 0,25 \mathrm{l} / \mathrm{ha}$ & $30.59^{\mathrm{b}}$ \\
\hline E. Kontrol & $27,18^{a b}$ \\
\hline
\end{tabular}

*Dari pemetikan terakhir (pemetikan ke-6)

Angka rata-rata yang diikuti oleh huruf yang sama menunjukkan tidak berbeda nyata menurut Uji Jarak Berganda Duncan pada taraf 0,05\%

\section{Pengaruh insektisida Asetamiprid 30\% terhadap fitotoksisitas pada tanaman teh}

Selama percobaan tidak terlihat adanya gejala fitotoksisitas pada tanaman teh yang diakibatkan oleh perlakuan insektisida Asetamiprid $30 \%$. Dari hasil pengamatan pada tanaman, tidak terdapat gejala keracunan akibat penyemprotan Asetamiprid $30 \%$ baik pada pucuk, daun muda maupun daun tua. Dengan demikian insektisida Asetamiprid 30\% aman terhadap tanaman teh. Diketahui bahwa insektisida Asetamiprid 30\% juga aman terhadap operator/petugas, karena bentuknya yang berupa cairan tidak menimbulkan iritasi pada kulit maupun mengganggu inhalasi operator/petugas. Selain mekanisme kerja insektisida secara kontak dan lambung, Asetamiprid juga memiliki tingakt efikasi yang tinggi dengan toksisitas yang relatif rendah. Bahan aktif Asetamiprid tidak ditemukan bukti karsinogenisitas, neurotoksisitas, mutagenisitas atau gangguan endokrin. Asetamiprid dapat menjadi bahan aktif alternatif untuk menggantikan insektisida organofosfat, yang telah menyebabkan pencemaran lingkungan yang parah dan dilarang di banyak negara (U.S. Environmental Protection Agency, 2002).

\section{KESIMPULAN}

Insektisida Asetamiprid $30 \%$ pada dosis 0.5 ; 0.75; dan $1 \mathrm{l} /$ ha dapat menekan intensitas serangan ulat penggulung pucuk pada tanaman teh setelah tiga kali penyemprotan dengan tingkat efektivitas lebih dari $70 \%$.

\section{DAFTAR PUSTAKA}

Chen, M., Zhao, J.Z. and Shelton, A.M., 2007. Control of Contarinia nasturtii Keiffer (Diptera: Cecidomyiidea) by foliar sprays of acetamiprid on cauliflower transplants. Crop Protection, 26(10), pp.1574-1578.

Hudayya, A., dan Jayanti, H. 2012. Pengelompokan Pestisida Berdasarkan Cara Kerjanya (Mode of Action). Bandung : Yayasan Bina Tani Sejahtera.

Insecticide Resistance Action Committee. 2016. IRAC Mode of Action Classification 
Scheme. IRAC Resistance Action Committee. Diperoleh dari : www.iraconline.org/documents/moa-

classification/?ext=pdf [Diakses $18 / 12 / 2016]$

Pusat Penelitian Teh dan Kina. 2006. Petunjuk Teknis Budidaya Tanaman Teh.

Peraturan Menteri Pertanian Republik Indonesia nomor 50/Permentan/OT.140/4/2014. 2014. Pedoman Teknis Budidaya Teh yang Baik. Jakarta.

United States Environmental Protection Agency (EPA). 2002. Pesticide Fact Sheet. https://www3.epa.gov/pesticides/chem_s earch/reg_actions/registration/fs_PC-

099050_15-Mar-02.pdf [1 Oktober 2016] 